International Journal of Instruction e-ISSN: 1308-1470 • www.e-iji.net
October $2020 \bullet$ Vol.13, No.4

p-ISSN: 1694-609X

pp. $763-780$

Received: 27/07/2019

Revision: 12/05/2020

Accepted: 02/06/2020

OnlineFirst:22/08/2020

\title{
The New Generation Self-Directed Teaching Materials of Natural Science in Elementary Schools Validity Tests
}

\author{
A. A. Ketut Budiastra \\ Dr, Faculty of Teacher Training and Education, Universitas Terbuka, Indonesia, \\ budiastra@ecampus.ut.ac.id
}

\section{Iwan Wicaksono}

Dr, Faculty of Teacher Training and Education, University of Jember, Indonesia, iwanwicaksono.fkip@unej.ac.id

\section{Gusti Made Sanjaya}

Dr, Postgraduate Program, Surabaya State University, Indonesia, igmasanjaya@unesa.ac.id

\begin{abstract}
The new generation of natural science teaching material in elementary school is the teaching material that utilizes inquiry-based learning in most parts of the tutorial and the provided material. The updating of teaching materials is an activity that must be carried out by the Universitas Terbuka to assure that the quality is following the development of science and knowledge. The study aims to test content, construct, and face validation along with the reliability by the experts upon the new generation self-directed natural science teaching materials in elementary schools following the scientific process. The validation process was conducted through Focus Group Discussion (FGD) in June 2019, which involved the interaction with the experts on teaching material, device, and media development. The instruments of teaching material validity are reviewed based on the content, construct, and face validity by employing Aiken's formula analysis for Content Validity Coefficient (CVC). Moreover, the instrument reliability is by using a One-way ANOVA analysis and Cronbach Alpha formula for Intraclass Correlation Coefficients (ICC). The results of validity assessment in average are $\mathrm{CVC} \geq 0.8$ categorized as high validity and $0.4<\mathrm{CVC}<0.8$ classified as medium validity. The level of agreement reliability between experts generates the significance of $\mathrm{p}$-value $>0.05$. Hence there are no significant differences in the assessment of the experts. The level of the experts' reliability is on average of ICC $\geq 0.8$, which is categorized as good.
\end{abstract}

Keywords: teaching materials, content validity, construct validity, face validity, selfdirected learning skills

Citation: Budiastra, A. A. K., Wicaksono, I., \& Sanjaya, I. G. M. (2020). The New Generation SelfDirected Teaching Materials of Natural Science in Elementary Schools Validity Tests. International Journal of Instruction, 13(4), 763-780. https://doi.org/10.29333/iji.2020.13447a 


\section{INTRODUCTION}

Teaching material have various types and qualities. Teaching materials is one of the material devices in tutorial activity, systematically composed and displays completely of the competence mastered by the students (McLaren \& Kenny, 2015). The function of teaching materials is critical when helping the tutor to do the tutorial activity. Teaching material development direction is designed for the students to be able to find the concepts, procedures, and be able to apply them in solving the given situation (Roy, Guay, \& Valois, 2013; Forsyth, 2014). The contextual presented material is intended to make the study of material adapted to the learning environment and easily understood by students. The results of the study show that teaching materials that can improve thinking skills are also teaching materials that are independent in nature (Hung, Chen, \& Huang, 2017). It means that the teaching material can be independently studied because it is systematic and complete, so it is beneficial in the learning process.

Universitas Terbuka organizes remote education in which the students are separated from the tutors, and their learning uses various learning resources. Nevertheless, printed materials are the main learning resources for the students of Universitas Terbuka (Sadjati, Yuliana, \& Suparti, 2017). In these circumstances, teaching materials are a substantially crucial learning resource to provide educational services to the groups of people who cannot attend face-to-face education. It is held in various forms, modes, and coverage supported by learning facilities and services as well as assessment systems that guarantee the quality of the graduates are following national education standards (Caswell, Henson, Jensen, \& Wiley, 2008). According to Butcher (2015), teaching materials should have the following characteristics:

(1) self-instructional, students are able to teach themselves, so some goals clearly formulated the final goal. Besides, it eases the students to study thoroughly by providing teaching material that is manifested into more specific units or activities;

(2) self-contained, all competency material that is thoroughly studied to make it easier for students to understand it;

(3) stand-alone, dependent not on other teaching materials so that they can be used independently;

(4) adaptive, which contains material that can increase students' knowledge regarding the development of the times and science and technology;

(5) user-friendly, which makes it easier for students to get information as clearly as possible.

The remote education system requires students to be able to learn self-directed learning by utilizing various teaching materials and learning assistance services (Richter \& McPherson, 2012). To learn self-directed skills in the context of the system affects the utilization of information and communication technology, which means various media are available as teaching material (Sediyaningsih, 2018). The results of the study show that self-directed learning skills require a great responsibility for students so they can try to do various activities to achieve goals (Rolfe, 2012; Wiley, Bliss, \& McEwen, 2014). 
Learning ability depends on the speed of reading and the ability to understand the content. In practical self-directed learning skills, students must have self-discipline, initiative, and strong learning motivation. Students must also have the capability to efficiently manage their time, hence able to study regularly based on the self-regulated schedule (Pucciarelli \& Kaplan, 2016).

It is a need to develop teaching materials that synch with the tutorial activities and characteristics of students as well as directed to the changes of student behavior following the learning outcomes (Broto \& Irianto, 2017). In the context of developing teaching materials, product design requires a validation process. Validation is a process to collect the shreds of evidence, which may support then inference from the utilization of measurement specifically (Baldus, Voorhees, \& Calantone, 2015). Validity means to what extent the accuracy of measuring or accuracy of measuring instruments in measuring the attributes that are the objective of measurement. The purpose of the implementation of validation is that all objects testing of teaching materials will always achieve the desired results continuously (Steyerberg \& Harrell, 2016). The product design validation process is carried out by experts in the related field. Based on the results of the expert validation, there is a possibility that the product design still needs to be improved according to the validator's suggestions.

The analysis results of the use of Universitas Terbuka printed and online teaching materials were taken from a set of 20 questions questionnaire. Utilization of teaching materials is the best known and used facility by students including $11.4 \%$ strongly disagree; $18.4 \%$ disagree; $31.3 \%$ doubt; $31.7 \%$ agree, and $7.2 \%$ of respondents who strongly agree to access Universitas Terbuka printed and online teaching materials. The data show the lack of students in utilizing teaching materials. In general, they only know but have not been able to use them. Based on the 2016 final semester examination results data, for elementary education study students who took natural science learning courses in elementary schools, students got difficulties in understanding the material as evidenced by the low score obtained when the assessment was conducted. The teaching materials have not inspired the principles of natural science that can be applied in the students' daily lives. Based on the results of observations and analysis from September to November of 2018 on the students who have taken the course, the students were less directed to be able to design, implement, evaluate, and analyze the process and results of natural science learning using approaches, methods, tools, and learning media that are relevant with the material and indicators that must be achieved (Budiastra, Erlina, \& Wicaksono, 2019).

The development of teaching materials is carried out based on a systematic process so that the validity and reliability of teaching materials can be guaranteed (Kaye \& Rumble, 2018). One of the stages of the development process is the validation utilized to obtain the appropriate data from the variables studied, namely self-directed learning skills. The type of validity that is present in the development process is the content, construct, and face validity (Krippendorff, 2018). Content validity is a representation and relevance of a set of items used to measure a concept carried out through rational analysis of needs based on the state of the art of science. Construct validity is an instrument that shows the 
extent to which the instrument can reveal the theoretical constructs to be measured in terms of consistency of design and logic of all supporting components of teaching materials. Face validity is items that are used to measure concepts in teaching materials and provide assessments that can uncover the concepts to be measured and their appearance. Additionally, the design of teaching material writing must be adjusted to the learning rules because it will be used by tutors to help and support the tutorial process (Daniel, 2017).

In Universitas Terbuka context, there is a problem where the previous development process of teaching materials of natural science in elementary schools was not in compliance with the materials development theories, as mentioned above. Thus, the study aims to test content, construct, and face validation along with the reliability by the experts upon the new generation self-directed natural science teaching materials in elementary schools following the scientific process. The new generation of teaching materials of natural science learning courses at elementary school is designed to foster student self-directed learning skills. The self-directed skill indicators embodied in the teaching materials of the new generation include (1) initiative and persistence in learning; (2) responsibility; (3) discipline and curiosity; (4) confidence and strong desire; and (5) organizing time and speed of learning (Broad, 2006). With the growth of self-directed learning in students, they are expected to be able to know when they need help from others and be able to identify sources of information (Pandiangan, Sanjaya, \& Jatmiko, 2017). The process of identifying this information source is needed to facilitate the learning process.

\section{METHOD}

The study used the Research and Development (R\&D) method in the form of teaching materials for natural science learning subjects in elementary schools. The new generation teaching materials will be used in the tutorial by implementing inquiry-based learning in most of the material presented. The process of product development results required planning design of teaching materials products. The $R \& D$ of the study is a combination of major steps in the cycle with the steps of the system approach model of educational R\&D from Gall \& Borg (1979), and Gall \& Borg (2007) as follows:

(1) research and information collection;

(2) identify instructional goals;

(3) conduct instructional analysis;

(4) analyze learners and contexts;

(5) write performance objectives;

(6) develop an assessment instrument;

(7) develop instructional strategy;

(8) develop and select instructional materials; 
(9) preliminary field testing;

(10) preliminary product revision;

(11) main testing field;

(12) operational product revision;

(13) operational field testing;

(14) final product revision;

(15) dissemination and implementation.

The results of the validity of the teaching materials of the natural science learning course at the elementary school are a series of the 9th stages of developing and selecting instructional materials. Validation activities used the Focus Group Discussion (FGD) technique in June 2019. Data sources were obtained from the results of the validation of three (3) validators, which were considered experts in science learning in elementary schools. The learning expert validator reviewed the new generation of teaching material that will be used in tutorial activities. The validator of the material discussed the contents of the new generation of science teaching materials in elementary schools by instructional objectives. The practitioner validator reviewed the implementation of the new generation of teaching materials in the tutorial activities. Data collection or information validity were taken from interaction with experts in developing instructional materials, devices, and learning media.

The instrument used to test the validity of the new generation teaching materials of natural science learning in elementary schools is the validation sheet (Setiani, Sanjaya, \& Jatmiko, 2019; Suprapto, 2019). The validity of teaching materials is reviewed based on the validation of content, construct, and face using Aiken's V formula analysis for Content Validity Coefficient (CVC) based on the results of expert judgment (Aravamudhan \& Krishnaveni, 2015). Besides, the reliability of the instrument uses a One-way ANOVA analysis to calculate the level of agreement between experts and the Alpha Cronbach formula to calculate the reliability of expert self-assessment (Gliem \& Gliem, 2003). Components of content validation instruments are rational analysis of needs based on the state of the art of science. The instrument component of construct validity is the consistency of the design and logic of all supporting components of teaching materials. The instrument component of face validity measures concepts in teaching materials and their appearance. The elements of teaching materials towards indicators of self-directed learning skills include (1) initiative and persistence in learning; (2) responsibility; (3) discipline and curiosity; (4) confidence and strong desire; and (5) organizing time and speed of learning (Broad, 2006).

The data analysis technique for the validity of the new generation teaching materials in elementary school learning used the Aiken's V formula, which is $\mathrm{CVC}=\sum \mathrm{S} /[\mathrm{n}(\mathrm{C}-1)]$ with $\mathrm{S}$ is $\mathrm{R}-$ Lo. Lo is the lowest value, $\mathrm{C}$ is the highest rating, and $\mathrm{R}$ is the number given by experts (Aravamudhan \& Krishnaveni, 2015). The CVC value category $\leq 0.4$ has low validity, $0.4<\mathrm{CVC}<0.8$ has moderate validity, and $\mathrm{CVC} \geq 0.8$ has high 
validity. The data analysis technique on the level of agreement reliability among the experts uses a One-way ANOVA on SPSS 24. If the results of the significance p-value are $>0.05$, then there is no significant difference in the assessment between experts. Besides, expert judgment reliability analysis techniques used Alpha Cronbach based on the results of Intraclass Correlation Coefficients (ICC) on SPSS 24. ICC value category $\leq 0.4$ has a low agreement, $0.4<$ ICC $<0.75$ has a good agreement, and ICC $\geq 0.8$ has a perfect agreement.

\section{FINDINGS}

The new generation teaching materials on natural science learning in elementary schools have been validated by three experts consisting of experts developing teaching materials, devices, and learning media. The results of the validity of the teaching material are reviewed based on the content, construct, and face validation. The validation of the content of the new generation teaching materials on natural science learning in elementary school needs analysis and state of the art components resulted in an average value of $0.4<\mathrm{CVC}<0.8$, which was 0.75 and 0.76 in the category of moderate validity. The level of agreement reliability among experts in the needs analysis and state of the art components resulted in a significance of $p$-value $>0.05$ which was equal to 0.78 and 0.86 so that there was no significant difference in the assessment among the experts. The reliability level of the expert needs analysis component produces an average value of ICC $\geq 0.8$ which is equal to 0.81 categorized as having a perfect agreement, and state of the art produces an average value of $0.4<$ ICC $<0.75$ which is 0.78 categorized as having a good agreement with expert evaluation. The results of the validation of the content of teaching materials for science learning in elementary schools can be shown in Table 1 .

Table 1

Content Validation Results

\begin{tabular}{|c|c|c|c|c|c|c|}
\hline No & Validation Components & $\mathrm{CVC}$ & Category & p-value & ICC & Category \\
\hline A. & \multicolumn{6}{|l|}{ Needs Analysis } \\
\hline 1 & $\begin{array}{l}\text { The nature of natural science learning } \\
\text { in elementary school }\end{array}$ & 0.67 & Moderate & & 0.74 & Good \\
\hline 2 & $\begin{array}{l}\text { Based on inquiry for self-directed } \\
\text { learning skills }\end{array}$ & 0.88 & High & & 0.87 & Excellent \\
\hline 3 & Compatibility with course profiles & 0.78 & Moderate & 0.78 & 0.84 & Excellent \\
\hline 4 & $\begin{array}{l}\text { Compatibility with remote open } \\
\text { learning systems }\end{array}$ & 0.88 & High & & 0.87 & Excellent \\
\hline 5 & Teaching material improvement & 0.56 & Moderate & & 0.71 & Good \\
\hline \multicolumn{2}{|r|}{ Average } & 0.75 & Moderate & & 0.81 & Excellent \\
\hline \multicolumn{7}{|c|}{ B. State of the art } \\
\hline 1 & Main source is from the latest journal & 0.78 & Moderate & \multirow{7}{*}{0.86} & 0.77 & Good \\
\hline 2 & The latest empirical result & 0.88 & High & & 0.8 & Excellent \\
\hline 3 & Refers to the latest theory & 0.56 & Moderate & & 0.69 & Good \\
\hline 4 & Planning and Implementation & 0.88 & High & & 0.8 & Excellent \\
\hline 5 & Learning environment & 0.67 & Moderate & & 0.73 & Good \\
\hline 6 & Encourage further research & 0.78 & Moderate & & 0.77 & Excellent \\
\hline \multicolumn{2}{|c|}{ Average } & 0.76 & Moderate & & 0.78 & Good \\
\hline
\end{tabular}


The results of the construct validation assessment of the new generation teaching materials of science learning in elementary component implementation and planning and evaluation resulted in an average CVC value of $\geq 0.8$, which was 0.82 and 0.83 in the category of high validity. Besides, the rational component, theoretical and empirical support, learning environment produces an average value of $0.4<\mathrm{CVC}<0.8$, which is $0.78,0.62$, and 0.67 in the category of moderate validity. The level of agreement reliability among rational component experts, theoretical and empirical support, implementation and planning, learning environment, and evaluation implementation resulted in the significance of $\mathrm{p}$-value $>0.05$, which amounted to $0.85,0.77,0.83,0.79$ and 0.88 so that there were no significant differences in assessment among the experts. The level of reliability of rational component experts, implementation and planning, and evaluation implementation resulted in an average value of ICC $\geq 0.8$, which was equal to 0.81 categorized as having a perfect agreement. In addition, theoretical and empirical support and learning environment produce an average value of $0.4<\mathrm{ICC}<0.75$, which is equal to 0.78 categorized as having a good agreement with experts' evaluation. The results of construct validation of natural science learning teaching materials in elementary schools can be shown in Table 2 .

Table 2

Construct Validity Result

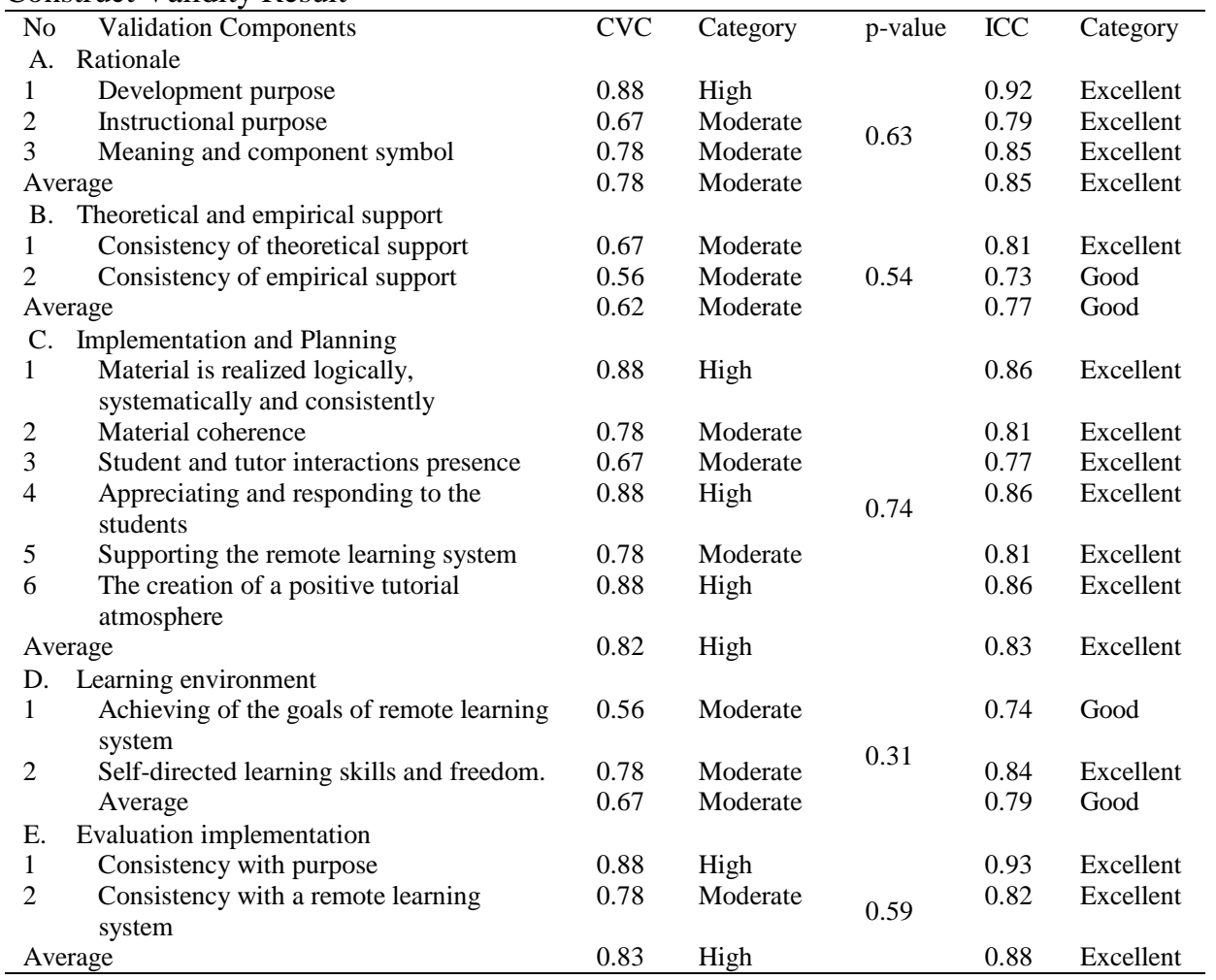


The assessment of face validation on the new generation teaching materials of natural science learning in elementary schools, components of the truth, concepts and languages resulted in an average CVC value of $\geq 0.8$ which was equal to 0.88 , and it is in the category of high validity. Additionally, the rules component in measurement and instrument format resulted in an average value of $0.4<\mathrm{CVC}<0.8$, which was 0.67 and 0.78 in the category of moderate validity. The level of reliability of agreement among experts on the concept of truth components, rules in measurement, instrument format, and language produced an average value of significance $p$-value $>0.05$ which was 0.82 so that there was no significant difference in the assessment between experts. The level of reliability of the expert component of agreement between experts in the concept of truth components, rules in measurement, instrument format, and language produces an average value of $\geq 0.8$, which is equal to 0.82 categorized as having a perfect agreement with expert judgment. The results of face validation of natural science learning teaching materials in elementary schools can be shown in Table 3 .

Table 3

Face Validity Result

\begin{tabular}{|c|c|c|c|c|c|c|}
\hline No & Validation Components & CVC & Category & p-value & ICC & Category \\
\hline 1 & Conceptual truth & 0.88 & High & \multirow{5}{*}{0.51} & 0.85 & Excellent \\
\hline 2 & Measurement standard & 0.67 & Moderate & & 0.76 & Excellent \\
\hline 3 & Instrument Format & 0.78 & Moderate & & 0.81 & Excellent \\
\hline 4 & Language & 0.88 & High & & 0.85 & Excellent \\
\hline \multicolumn{2}{|c|}{ Average } & 0.81 & High & & 0.82 & Excellent \\
\hline
\end{tabular}

The validation assessment of the new generation teaching materials of natural science learning in elementary schools self-directed learning skills of students in the components of competition and persistence, self-confidence, and a strong determination to learn has an average value of $C V C \geq 0.8$. Means 0.88 is categorized as high validity. In addition, the components of responsibility, discipline and curiosity, and managing the time and speed of learning results an average value of $0.4<\mathrm{CVC}<0.8$, which was $0.78,0.67$, and 0.78 in the category of moderate validity. The level of agreement reliability among the experts, the component of initiative and persistence, responsibility, discipline and curiosity, confidence and strong determination to learn, and organizing time and learning speed results in an average value of significance p-value $>0.05$ so that only 0.48 significant difference in the assessment among the experts. The experts level of reliability on the components of initiative and persistence, responsibility, responsibility, discipline and curiosity, confidence and a strong determination to learn, and organizing the time and speed of learning results an average value of 80.8 , which means 0.82 categorized as having the perfect agreement to the evaluation of the experts. The results of the validation of teaching the new generation materials of natural science learning in elementary schools for students of independent learning can be studied in Table 4. 
Table 4

Results of Validation of New Generation Teaching Materials on Self-directed Learning Skills

\begin{tabular}{|c|c|c|c|c|c|c|}
\hline No & Validation Components & $\mathrm{CVC}$ & Category & p-value & ICC & Category \\
\hline 1 & Initiative and persistence & 0.88 & High & \multirow{6}{*}{0.48} & 0.84 & Excellent \\
\hline 2 & Responsibility & 0.78 & Moderate & & 0.82 & Excellent \\
\hline 3 & Discipline and curiosity & 0.67 & Moderate & & 0.78 & Excellent \\
\hline 4 & $\begin{array}{l}\text { Confidence and strong } \\
\text { determination to learn }\end{array}$ & 0.88 & High & & 0.84 & Excellent \\
\hline 5 & $\begin{array}{l}\text { Organizing time and learning } \\
\text { speed }\end{array}$ & 0.78 & Moderate & & 0.82 & Excellent \\
\hline Ave & & 0.8 & High & & 0.82 & Excellent \\
\hline
\end{tabular}

\section{DISCUSSION}

\section{Content Validation}

Based on the data from content validation and reliability by experts in Table 1 , the components of needs analysis and state of the art indicate that the new generation teaching materials of natural science learning in elementary schools are worthy of being tested in tutorial activities to foster the student self-directed learning skills. In the needs analysis component, the nature of natural science learning in elementary school has three dimensions through product, process and attitude (Stuckey, Hofstein, MamlokNaaman, \& Eilks, 2013). The inquiry learning model encourages students who have self-directed learning skills that emphasize experiences that are appropriate to the challenges in the environment. The results of the study show that the compilation of inquiry activities, students provide opportunities to ask questions, ideas, build curiosity about everything in their environment, build skills and develop awareness in science learning to be very needed to be studied (Abd-El-Khalick, 2013).

The objective of the development of new generation teaching materials of natural science learning courses in elementary schools is that the students are expected to be able to design, implement and evaluate, and analyze the process and results of natural science learning using approaches, methods and tools and learning media in accordance with the material and indicators that must be achieved as stated in the applicable curriculum by considering the development and characteristics of students. The results of the study show that the quality of teaching materials is very dependent on the accuracy in calculating these factors in the development of teaching materials (Atenas \& Havemann, 2013).

Validation of content about components of conformity with open remote learning systems emphasizes the importance of system flexibility to minimize the constraints of place, time, and aspects caused by student characteristics. Teaching materials are developed for the remote education system as an alternative institution for the community to take part in educational programs due to scarcity of resources and high costs for participating in regular education programs (Yuan \& Powell, 2013). The stages of improvement in teaching materials on one component must be followed by 
improvements and adjustments on the other teaching material components, so that the whole and integrated teaching materials are obtained. The results of experts input on the teaching materials developed are input to improve the teaching materials and make the teaching materials qualified better (Downes, 2007).

In the state-of-the-art component, there is the need for references that describe information about related sources. The new generation teaching materials on natural science learning in elementary schools are compiled using the latest reference material and are used as a reference for more advanced. The results of the study show that scientific works use complete references, so scientific work quality is getting better and better (Kholodov, 2015). In addition to reference sources, teaching materials are composed based on empirical reviews which are the results of previous studies that present several concepts that are relevant and related to natural science learning in elementary schools. The results of the study indicate that teaching materials must be based on concepts, theories, and empirical facts that can be accounted for (Blumer, 2017).

The component of the application of teaching materials must consider planning and implementation, the role of a speaker in designing or compiling teaching materials is crucial to the success of the learning and learning process. With the teaching materials of a new generation of natural science learning in elementary schools, teachers will be more coherent in teaching material to students and achieving all predetermined competencies (Klopp \& Stark, 2018). The environment of the teaching and learning process is an influential learning resource in the learning process and student's development. The environment always surrounds students from time to time, so that between students and the environment there is a reciprocal relationship which the environment affects students and vice versa (Van der Kleij, Feskens, \& Eggen. 2015). The new generation teaching materials of natural science learning in elementary schools create an environment that includes all material and stimuli inside and outside the individual, both physiological, psychological and socio-cultural. The results of the study show that the learning environment that surrounds students both in the social and nonsocial environments influences the learning process of students (Kangas et al., 2017).

\section{Construct Validation}

Based on data from construct validation and reliability data from the experts in Table 2, the rational component, theoretical and empirical support, implementation and planning, learning environment, and evaluation show that the new generation teaching materials of natural science learning in elementary schools are worthy of testing in tutorial activities to develop student's self-directed learning skills. In the rational component, it is a description of the things that cause the need to do research on specific problem or problem that appears and is written in the form of description by containing information, such as the development, instructional, meaning and symbol components. Teaching materials developed must refer to the applicable curriculum, especially those related to the objectives and material in the Indonesian National Qualifications Framework (Jatmiko, Widodo, Martini, Wicaksono, \& Pandiangan, 2016). Theoretical support of the new generation teaching materials on natural science learning in elementary schools 
is based on thoughts or mindsets that base everything from existing theories as to the basis of their actions (Kent, Laslo, \& Rafaeli, 2016). Moreover, the teaching materials are also based on empirical support, namely observation of the reality of common sense and the results are not speculative.

The components of implementation and planning, the new generation teaching materials on natural science learning in elementary schools, tutors are required to be able to present teaching materials that encourage student activity. Presentation of teaching materials or subject matter is directed at the approaches to how to find out and how to do, to provide direct experience to students to develop their concepts that will give meaning to the knowledge gained (Howard, Gagné, Morin, \& Van den Broeck, 2016). The new generation teaching material is related to the achievement of general and specific instructional objectives so that the tutor understands the material to be taught as material facts, concepts, principles, and procedures. With the presence of new generation teaching materials, the process of interaction between students and tutors must show the existence of educational relationships. Interaction must be directed to a specific educational purpose, namely the change in student behavior to have selfdirected learning skills (Pandiangan et al., 2017). In the tutorial activities, the activities must be centered on students planning their teaching materials to be learned and implementing the tutorial process in learning the material. The role of the tutor is more permissive, namely allowing each activity carried out by students in learning whatever they want. It is relevant to the competencies that will be mastered by students after learning the teaching material.

The learning environment of the new generation teaching materials of natural science learning in elementary schools was created so that students have self-directed learning skills and they decide their own goals in learning and try to use methods that support their activities. The results of the study show that students who have self-directed learning skills are able to transfer learning, both knowledge and expertise from one situation to another (Broad, 2006). Every student can take the initiative, with or without the help of others, in diagnosing learning needs, formulating learning goals, identifying learning resources, choosing and implementing learning strategies that are appropriate for him, and evaluating his learning outcomes (Caswell et al., 2008).

Evaluation is important in the tutorial activities with teaching materials for a new generation of natural science learning in elementary schools so that students can understand the extent of students' understanding of the material presented and to also know the effectiveness of the teaching materials used. In addition, the evaluation also functions as a measuring tool, whether the objectives of the tutorial that have been formulated previously have been achieved or not (Wicaksono, Madlazim, \& Wasis, 2017). Evaluation of new generation teaching materials is not the result, but rather a process that takes place as long as the learning program takes place. The evaluation depends on the type of evaluation that is used. The type of evaluation used will influence an evaluator in determining procedures, methods, instruments, the timing of implementation, and data sources (Erlina, Susantini, Wasis, Wicaksono, \& Pandiangan, 2018). 


\section{Face Validation}

Based on data from construct validation and reliability data by experts in Table 3 , conceptual truth, rules of measurement, instrument format, language show that teaching materials for a new generation of natural science learning in elementary schools are worthy of testing in tutorial activities to foster students' self-directed learning skills. Component of conceptual truth, the collected data becomes valid through ways of collecting data in the validation process. The data obtained can be a supporter of the truth of a particular concept. An instrument is a tool used in tracing the symptoms that exist in the validation process to prove the truth or refute certain hypotheses (Gliem \& Gliem, 2003). Data collection in the validation process, researchers can use the available instruments and can also use self-made instruments. The use of available instruments is an instrument that has been set or standardized to collect predetermined variable validation process data. However, if the standard instrument is not yet available for certain variables in the study, the researcher can arrange the instrument itself which will be used by the researcher in conducting the validation process (Blumer, 2017).

The rule in measuring the validation instrument is a systematic process in assessing and distinguishing something that is measured. These measurements are arranged according to certain rules. Different rules require different scales and measurements. Data processing and analysis must consider the nature of the measurement scale used (Aravamudhan \& Krishnaveni, 2015). Mathematical operations and the choice of statistical equipment used in data processing, basically have certain requirements in terms of the scale of data measurement. The mismatch between the measurement scale and the statistical operation used will produce biased and inappropriate conclusions. The important principles in measurement are; numbers, determination, and rules (Krippendorff, 2018). Good measurement must have isomorphism with reality. In the principle of isomorphism, there is a close similarity between the social reality under study and the value obtained from the measurement (Boxenbaum \& Jonsson, 2017). Therefore, a measuring instrument is seen to be good if the results can reflect the reality of the phenomenon to be measured precisely.

Instruments are tools that are selected and used by researchers in their activities to collect data so that these activities become systematic. The instrument format component plays a very important role in determining the quality of a validation process because the validity of the data obtained will be largely determined by the quality of the instruments that are used, in addition to the data collection procedures that are performed (Kaye \& Rumble, 2018). This can be interpreted because the instrument functions are to reveal facts into data, so that if the instrument used has adequate quality in the sense of valid and reliable, the data obtained will be in accordance with the facts or the actual situation. If the quality of the instrument used is not good in the sense of having low validity and reliability, then the obtained data is also invalid or not in accordance with the facts. Hence it can produce false conclusions (Steyerberg \& Harrell, 2016).

The variety of standard written languages in the instrument validation can be viewed from standard terms, which are used with the correct meaning. One term or word is said 
to be standard if its formation and method of writing are following the rules for forming Indonesian terms (Solihati \& Hikmat, 2018). The written language in the validation instrument can be understood well if the sentences that have been written are in accordance with the rules that apply in that language. Furthermore, punctuation plays an important role because if it is incomplete, it can cause the contents of the writing difficult to understand. Components of language based on spelling are rules that must be adhered to by written language users. Regularity in the form will have implications for the accuracy and clarity of meaning. The results of the study indicate that the use of language in a validation instrument means that it is focusing on a language as a communication tool in the form of writing (Sulfasyah, Bahri, \& Saleh, 2018).

\section{Teaching Materials Validation to Grow Self-directed Learning Skills}

Based on the data from the validation of teaching materials to foster self-directed learning skills and reliability by experts in Table 4, the components of initiative and persistence, responsibility, discipline and curiosity, confidence and a strong desire to learn, organize time and speed of learning show that the new generation teaching material of natural science learning in elementary schools is worthy of being tested in tutorial activities to foster student self-directed learning skills. The material in the development of new generation teaching materials for natural science learning in elementary schools is the material that is able to make students having self-directed learning skills, which includes (1) providing interesting examples and illustrations in order to support the material presentation; (2) provide the possibility for students to provide feedback or measure their mastery on the material provided by providing practice questions, and independent assignments; and (3) contextual through the material presented related to the atmosphere or task context and student environment. The language that is used is quite simple because students only deal with teaching materials when studying independently (Yuan \& Powell, 2013).

The component of initiative and persistence in the new generation teaching materials encourages students to have their initiatives and habits. The ability to recognize problems or opportunities and be able to take action to solve problems. When students have an initiative, they can immediately see the problems that arise and find solutions so that problems can be solved (Blumer, 2017). Self-persistence and learning habits of each student need to be improved to support the process of successful natural science learning in elementary school. This is where the potential role of new generation teaching materials to increase self-persistence or the determination and learning habits of students in addition to external factors are also needed. In addition, persistence for students is a continuation of voluntary actions taken to achieve a goal despite obstacles, difficulties or despair (Rolfe, 2012; Wiley et al., 2014).

The component of learning responsibility has a very important role in efforts to improve student learning autonomy. Responsibility is a student's awareness of intentional or unintentional behavior or actions. Responsibility also means acting as an embodiment of awareness of its obligations (Richter \& McPherson, 2012). New generation teaching materials encourage students to be more mature and become better individuals so that in solving problems, students will be more confident. Indicators that may support the 
responsibility of learning new generation teaching materials are carrying out and completing tasks seriously, keeping promises, and accepting the consequences of their actions (Pandiangan et al., 2017).

In studying the teaching materials of the new generation, confidence is needed in solving problems. Confidence shows the quality needed to make students self-assured and responsible. However, self-confidence is not something that can be taught to individuals from day to day but must be embedded in the learning process (Hung et al., 2017). Based on this description, it appears that the orientation of natural science learning in elementary school fosters the students' strong determination for learning. The tutorial successfully uses this teaching material through the interaction of tutors in the tutorial to student behavior as a reciprocal of the process. Student behavior when studying new generation teaching materials, can indicate interest and a sign of student interest in the material (Klopp \& Stark, 2018).

Organizing the time and pace of learning in realizing a learning environment through regulating how long students will need time to practice a task and how high students in new generation teaching materials do the intensity of the task on natural science learning in elementary schools. Time is an important aspect of the structure of the implementation of the tutorial and can be used by tutors to create a more productive learning environment (Rolfe, 2012). The results of the study show that how long it takes students to practice completing a task before moving on to the next task (Wiley et al., 2014). In the use of new generation teaching materials, the tutor must first decide on aspects related to time. Decisions about when to transfer student activities to other assignments or change assignments performed by students are usually based solely on what the tutor sees from student progress when the process takes place when learning new generation teaching materials.

In the process of learning science in elementary schools, students are not only given knowledge or various memorized facts, but students are required to use the mind to study natural phenomena actively. The new generation teaching materials of natural science learning does not only discuss mastery of facts, concepts, and principles about nature but also about methods of problem-solving; practice the ability to think critically and draw conclusions; practice to be objective, teamwork and appreciate the opinions of others. Content validation, construct, and advance validation activities provide the feasibility of new generation teaching materials that are suitable for natural science learning in elementary schools so that they are expected to foster students' independent learning skills. The process of identifying sources of information in this new generation of teaching materials is needed to expedite the learning process of new students. The Universitas Terbuka students enter the world of distance education, which has unique learning characteristics that are in some ways different from the face-to-face teaching that they have been undergoing to become independent students who excel, not a dream.

\section{CONCLUSION}

Based on the results of the validation process and discussion above about the validity of the content, constructs, faces, and validation of teaching materials to foster self-directed 
learning skills and reliability of new generation teaching materials in valid categories to promote student self-directed learning skills. Evaluation of the validity of new generation teaching materials of natural science learning in elementary school was obtained by the average CVC value of 0.8 in the category of high validity and $0.4<$ CVC $<0.8$ in the category of moderate validity. The level of agreement reliability among experts produced a significance of p-value $>0.05$, so there was no significant difference towards the assessment among experts, the level of reliability of experts on the average ICC value $\geq 0.8$ categorized as having a perfect agreement and $0.4<$ ICC $<$ 0.75 categorized as having a good agreement. The first recommendation of the study to UT and its tutors are that the new generation self-directed teaching materials of natural science learning in elementary schools are worthy of being piloted in tutorial activities. The study also recommends that self-directed teaching materials developers, especially in distance education, conduct a validation and reliability test of the teaching materials that are being developed so that they comply with scientific process.

\section{ACKNOWLEDGEMENTS}

Our gratitude goes to the Universitas Terbuka Research and Community Service through a superior applied research scheme with contract number 12419/UN31.LPPM/PM/2019 for funding support for the completion of this research. Our thanks also go to the experts who have provided input and suggestions for the perfection of the new generation teaching materials on natural science learning in elementary schools.

\section{REFERENCES}

Abd-El-Khalick, F. (2013). Teaching with and about nature of science, and science teacher knowledge domains. Science \& Education, 22(9), 2087-2107.

Aravamudhan, N. R., \& Krishnaveni, R. (2015). Recruitment and selection building scale: Content validity evidence. SCMS Journal of Indian Management, 12(3), 58-73.

Atenas, J., \& Havemann, L. (2013). Quality assurance in the open: an evaluation of OER repositories. Innoqual: The International Journal for Innovation and Quality in Learning, 1(2), 22-34.

Baldus, B. J., Voorhees, C., \& Calantone, R. (2015). Online brand community engagement: Scale development and validation. Journal of Business Research, 68(5), 978-985.

Blumer, H. (2017). Methodological principles of empirical science. London: Routledge.

Boxenbaum, E., \& Jonsson, S. (2017). Isomorphism, diffusion, and decoupling: Concept evolution and theoretical challenges. London: Sage Publications.

Broad, J. (2006). Interpretations of independent learning in further education. Journal of Further and Higher Education, 30(2) 119-143.

Broto, M. F., \& Irianto, L. B. (2017). Evaluasi kualitas substansi Buku Materi Pokok (BMP) FISIP-UT [Evaluation of the substance quality of the Printed Material]. Jurnal Pendidikan Terbuka dan Jarak Jauh, 16(1), 48-57. 
Budiastra, A. A. K., Erlina, N., \& Wicaksono, I. (2019). Video-based interaction through teacher working group forum to increase elementary school teachers' professionalism. New Educational Review, 57, 187-199.

Butcher, N. (2015). A basic guide to open educational resources (OER): Commonwealth of learning (COL). France: United Nations Educational.

Caswell, T., Henson, S., Jensen, M., \& Wiley, D. (2008). Open content and open educational resources: Enabling universal education. The International Review of Research in Open and Distributed Learning, 9(1), 1-10.

Daniel, B. K. (2017). Big data in higher education: The big picture. New York, NY: Springer.

Downes, S. (2007). Models for sustainable open educational resources. Interdisciplinary Journal of E-Learning and Learning Objects, 3(1), 29-44.

Erlina, N., Susantini, E., Wasis, Wicaksono, I., \& Pandiangan, P. (2018). The effectiveness of evidence-based reasoning in inquiry-based physics teaching to increase students' scientific reasoning. Journal of Baltic Science Education, 17(6), 972-985.

Forsyth, I. (2014). Teaching and learning materials and the internet. London: Routledge.

Gall, M. D., \& Borg, W. R. (1979). Educational research: An introduction. USA: Pearson Education, Inc.

Gall, M. D., Gall, J. P., \& Borg, W. R. (2007). Educational research: An introduction. New York: Longman Inc.

Gliem, J. A., \& Gliem, R. R. (2003). Calculating, interpreting, and reporting Cronbach's alpha reliability coefficient for Likert-type scales. Conference in Adult, Continuing, and Community Education, 2(1), 82-88

Howard, J., Gagné, M., Morin, A. J. S., \& Van den Broeck, A. (2016). Motivation profiles at work: A self-determination theory approach. Journal of Vocational Behavior, 95, 74-89.

Hung, Y. H., Chen, C. H., \& Huang, S. W. (2017). Applying augmented reality to enhance learning: A study of different teaching materials. Journal of Computer Assisted Learning, 33(3), 252-266.

Jatmiko, B., Widodo, W., Martini, B. M., Wicaksono, I., \& Pandiangan, P. (2016). Effectiveness of the INQF-based on learning on a general physics for improving student's learning outcomes. Journal of Baltic Science Education, 15(4), 441-451.

Kangas, M., Siklander, P., Randolph, J., \& Ruokamo, H. (2017). Teachers' engagement and students' satisfaction with a playful learning environment. Teaching and Teacher Education, 63, 274-284. 
Kaye, A. T., \& Rumble, G. (2018). Distance teaching for higher and adult education. London: Routledge.

Kent, C., Laslo, E., \& Rafaeli, S. (2016). Interactivity in online discussions and learning outcomes. Computers \& Education, 97, 116-128.

Kholodov, A. S. (2015). Citation indexes of scientific works. Herald of the Russian Academy of Sciences, 85(2), 122-131.

Klopp, E., \& Stark, R. (2018). Learning scientific explanations by means of worked examples-promoting psychology students' explanation competence. Psychology Learning \& Teaching, 17(2), 144-165.

Krippendorff, K. (2018). Content analysis: An introduction to its methodology. London: Sage Publications.

McLaren, H. J., \& Kenny, P. L. (2015). Motivating change from lecture-tutorial modes to less traditional forms of teaching. The Australian Universities' Review, 57(1), 26-38.

Pandiangan, P., Sanjaya, M., Gusti, I., \& Jatmiko, B. (2017). The validity and effectiveness of physics independent learning model to improve physics problem solving and self-directed learning skills of students in open and distance education systems. Journal of Baltic Science Education, 16(5), 651-665.

Pucciarelli, F., \& Kaplan, A. (2016). Competition and strategy in higher education: Managing complexity and uncertainty. Business Horizons, 59(3), 311-320.

Richter, T., \& McPherson, M. (2012). Open educational resources: Education for the world. Distance Education, 33(2), 201-219.

Rolfe, V. (2012). Open educational resources: Staff attitudes and awareness. Research in Learning Technology, 20, 1-13.

Roy, A., Guay, F., \& Valois, P. (2013). Teaching to address diverse learning needs: Development and validation of a differentiated instruction scale. International Journal of Inclusive Education, 17(11), 1186-1204.

Sadjati, I. M., Yuliana, E., \& Suparti. (2017). Peningkatan kualitas buku materi pokok berdasarkan hasil uji coba lapangan [Quality improvement of basic material books based on field test results]. Jurnal Pendidikan Terbuka dan Jarak Jauh, 15(2), 99-111.

Sediyaningsih, S. (2018). Konvergensi media di era digital (eksploitasi media komunikasi dalam proses belajar mengajar di era digital) [Media convergence in the digital era (exploitation of communication media in the teaching and learning process in the digital era)]. Jurnal Pendidikan Terbuka dan Jarak Jauh, 19(1), 52-57.

Setiani, R., Sanjaya, I., \& Jatmiko, B. (2019). ARICESA as an alternative learning model to improve learning motivation and understanding of student concepts. International Journal of Instruction, 12(2), 383-398. 
Solihati, N., \& Hikmat, A. (2018). Critical thinking tasks manifested in Indonesian language textbooks for senior secondary students. London: Sage Publications.

Steyerberg, E. W., \& Harrell, F. E. (2016). Prediction models need appropriate internal, internal-external, and external validation. Journal of Clinical Epidemiology, 69, 245247.

Stuckey, M., Hofstein, A., Mamlok-Naaman, R., \& Eilks, I. (2013). The meaning of 'relevance' in science education and its implications for the science curriculum. Studies in Science Education, 49(1), 1-34.

Sulfasyah, S., Bahri, A., \& Saleh, S. F. (2018). Writing lessons in grade 1 Indonesian thematic textbooks: A content analysis. Indonesian Journal of Applied Linguistics, 7(3), 495-503.

Suprapto, N. (2019). Development and validation of students' perception on learning by questioning scale in Physics. International Journal of Instruction, 12(2), 243-258.

Van der Kleij, F. M., Feskens, R. C. W., \& Eggen, T. J. H. M. (2015). Effects of feedback in a computer-based learning environment on students' learning outcomes: A meta-analysis. Review of Educational Research, 85(4), 475-511.

Wicaksono, I., Madlazim, \& Wasis. (2017). The effectiveness of virtual science teaching model (VS-TM) to improve student's scientific creativity and concept mastery on senior high school physics subject. Journal of Baltic Science Education, 16(4), 549561

Wiley, D., Bliss, T. J., \& McEwen, M. (2014). Open educational resources: A review of the literature. New York, NY: Springer.

Yuan, L., \& Powell, S. J. (2013). MOOCs and open education: Implications for higher education. Bolton: The University of Bolton. 